\title{
補強土擁壁の地震時変位量計算手法の構築及び 実被害事例への適用
}

\author{
中島進1・古関潤一2・渡辺健治 ${ }^{3}$ ・舘山勝3
}

\begin{abstract}
模型振動台実験における補強土壁の地震時挙動を反映して，支持地盤及び背面盛土の地盤変形の影響を考慮 したジオグリッド補強土擁壁の地震時変位量計算手法を構築し, 過去に実施した模型振動台実験の再現解析を 実施した．提案手法では，地盤変形の影響を考慮することによって，剛体釣り合いを想定したNewmark法では 考慮できない低加速度レベルから生じる変位量増分を評価することが出来る．提案手法を既往の補強土壁に関 する振動台実験に適用した結果, 計算値と実測值は比較的良好に一致した。 また, 提案手法の実物大構造物一 の適用性を検証するために，兵庫県南部地震において被災した補強土壁の実被害事例解析も行った．
\end{abstract}

キーワード : ジオグリッド補強土擁壁, 振動台実験, 残留変位量, Newmark法, 被害事例解析

\section{1.はじめに}

1995年の兵庫県南部地震では，多数の鉄道盛土を支 える従来型の重力式・もたれ式擁壁が被災し甚大な被 害を受けた。一方で，剛な一体型壁面工を有するジオ テキスタイル補強土擁壁は補修可能な程度の軽微な残 留変位を示すにとどまっだ1).

以降の大地震においても，補強土擁壁が完全に倒壊 するような被害事例は無く，補強土擁壁の設計に当た っては従来の極限釣合い法による設計ではなく，その 粘り強い変形性能を考慮するために，地震後に生じる 残留変位量によって，その性能を評価する性能照査型 設計法への移行が望まれている。実際に鉄道構造物の 設計標準2における補強土擁壁の設計では，L2 地震動 に対して，堀井ら ${ }^{3)}$ が提案したNermark法) とエネルギー 一定則を用いた手法による変位量照査が採用されてい る.

筆者らはこれまで補強土擁壁の地震時挙動に着目し て模型振動台実験)を実施してきた，その結果，(1)補強 土壁の粘り強い変形性能は，擁壁変位に伴って増大寸 る補強材張力, 引抜抵抗に起因すること，(2)補強材の 配置が補強土壁の耐震性に顕著な影響を及ぼすこと, (3)剛壁面を有する補強土壁の場合，背面補強領域のせ ん断変形と共に擁壁の変位が増大寸ることなどを明ら かにしてきた。

これらの知見に基づき，筆者らは補強土壁の地震時 残留変位量の評価法の構築に取り組んできた6). 本研究 では，文献6)での変位量評価法を基にして，振動台実 験における地震時挙動を反映し，その改良·修正を図り， 新たな変位量評価法を構築した上で，これまで実施し てきた振動台実験の再現解析を行った．また，兵庫県

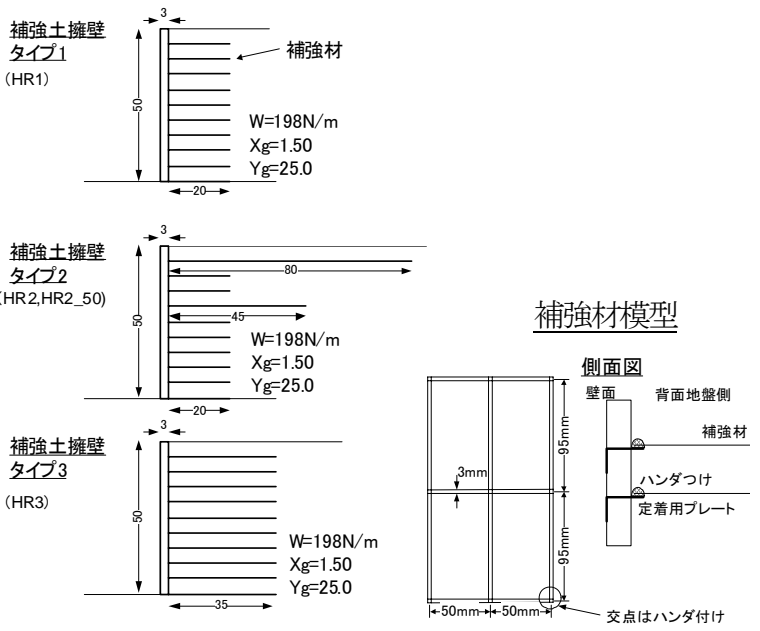

図-1 擁壁模型(単位：cm)及び補強材模型（単位：mm)

南部地震における被災事例に適用を試みたので，その 結果についても報告する.

\section{2. 振動台実験の実験方法}

本研究における振動台実験で使用した補強土壁模型 を図-1 に，典型的な実験模型の断面図を図-2 に示寸.

図-2 には，後述する重力式擁壁に関する実験 $(\mathrm{HGir})^{5)}$ の 模型断面も併せて示した。模型地盤は気乾状態の豊浦 砂を用いて，空中落下法で相対密度が $90 \%$ となるよ うに調整して作製した。補強材配置としては，壁面高 さ $50 \mathrm{~cm}$ 擁壁模型に対して，長さ $20 \mathrm{~cm}$ のジオグリッ ド補強材模型を 10 層配置したタイプ 1 , 最上層及び下 から 7 層目の補強材をそれぞれ $80 \mathrm{~cm}, 45 \mathrm{~cm}$ まで延長 したタイプ 2，全層 $35 \mathrm{~cm}$ ま゙延長したタイプ 3 の 3 通

\footnotetext{
1正会員，（独）土木研究所（テ305-8516 茨城県つくば市南原 1-6)

2正会員，東京大学 生産技術研究所（干153-8505 東京都目黒区駒場 4-6-1）

正会員, 鉄道総合技術研究所 構造物技術研究部（广185-8540 東京都国分寺市光町 2-8-38)
} 


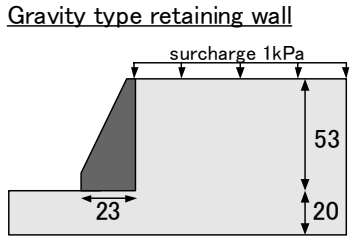

Reinforced soil retaining wall

図-2 実験模型の典型的な断面図(単位 $\mathrm{cm}$ )

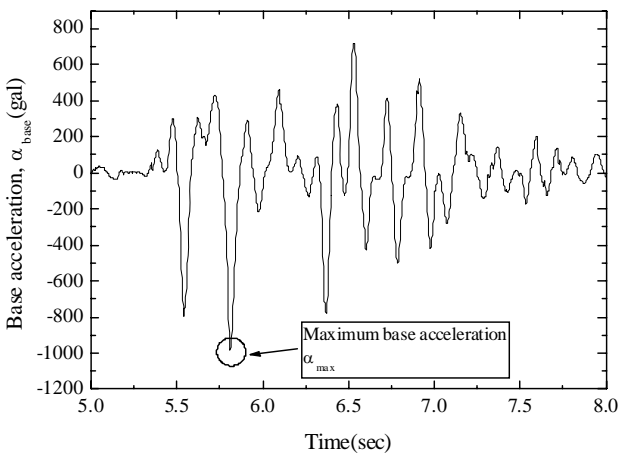

図-3 典型的な不規則波の例

表-1＼cjkstart実験条件のまとめ

\begin{tabular}{|c|c|c|c|c|c|}
\hline ケース名 & 擁壁タイプ & 支持地盤条件 & 加振波形 & 加振条件 & 参考文献 \\
\hline HR1 & 補強土タイプ1 & 水平 $/ 20 \mathrm{~cm}$ & 規則波 & 段階加振 & 文献(5) \\
\hline HR2 & 補強土タイプ2 & 水平 $/ 20 \mathrm{~cm}$ & 不規則波 & 段階加振 & 文献(5) \\
\hline HR2_50 & 補強土タイプ2 & 水平 $/ 5 \mathrm{~cm}$ & 正弦波 & 段階加振 & 久献(6) \\
\hline HR3 & 補強土タイプ3 & 水平 $/ 20 \mathrm{~cm}$ & 不規則波 & 段階加振 & 文献(5) \\
\hline
\end{tabular}

りで，層間隔は全タイプで $5 \mathrm{~cm}$ である.

補強材模型は5)，幅 $3 \mathrm{~mm}$ ，厚さ $0.1 \mathrm{~mm} の り$ 青銅板の 交点をハンダ付けして格子状に組み合わせたもの（図1 参照）を使用した。壁面との定着もハンダで行い, 十分な定着強度を確保した。模型地盤は支持地盤，背 面地盤共に気乾状態の豊浦砂を用いてホッパーによる 空中落下法で相対密度が $90 \%$ となる様に作製した。

加振は不規則波（図-3 参照）または正弦波（5 Hz， 20 波）を用いて行い，最大加速度をそれぞれ約 100 gal(不規則波)または 50 gal(正弦波)ずつ増大させて， 擁壁が大変位に至るまで加振を継続した.

表-1 に実験条件をまとめた．各実験を参照する際に, 以下では表中の実験ケース名を用いる。なお、実験方 法の詳細については文献(5)を参照されたい.

\section{3. 実験結果}

\section{（1）残留変位量及び地震時挙動の比較}

各加振終了時の残留変位量と振動台最大加速度の関 係を図-4，5に示す．残留変位量として，本研究では壁 面の滑動量と転倒角度に着目した.

まず、従来型擁壁との比較として、HGir (図-2参照) とHR1〜3との違いに着目すると、加速度の増大と共に 擁壁の滑動量、転倒角度の両者ともに重力式擁壁の方 が顕著な増大傾向を示している．特に、重力式擁壁の 場合には、背面地盤に滑り面が発生(図-4, 5中、矢印 で示す)すると、変位量の増大傾向がより顕著になって

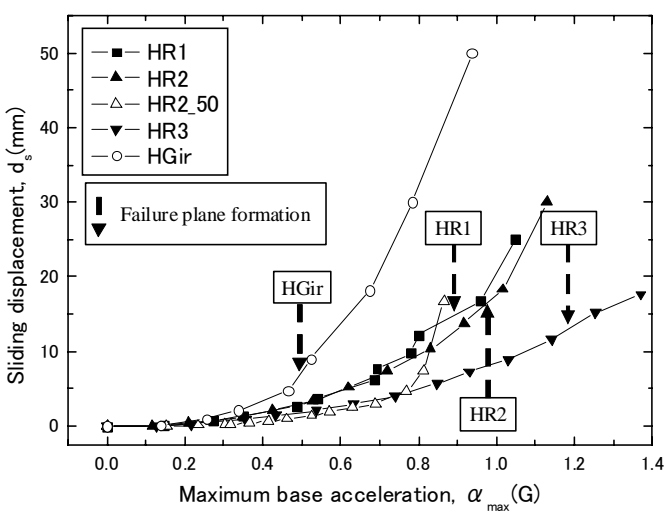

図-4 残留滑動量の比較

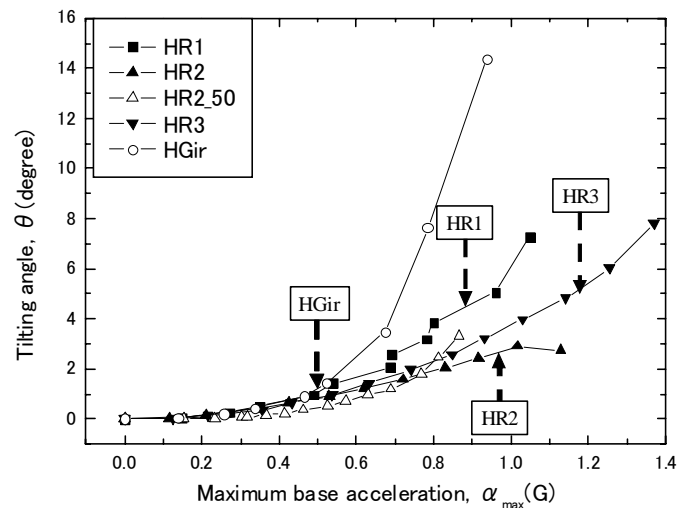

図-5 残留転倒量の比較

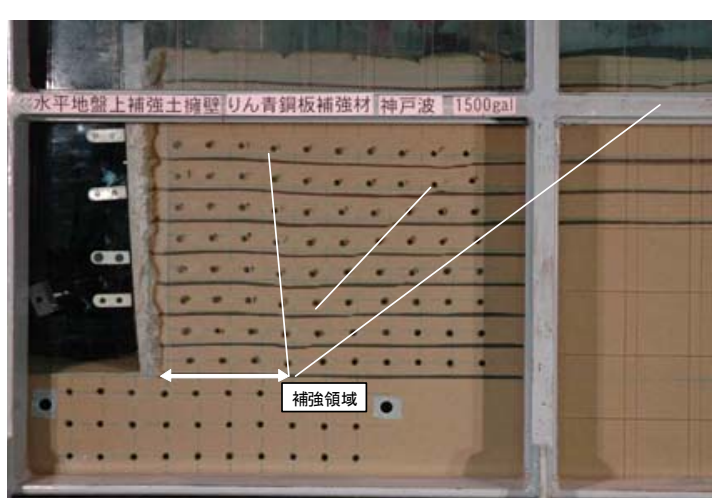

図-6 背面地盤の変形状況?

いる。一方で、補強土擁壁の場合には、背面地盤に滑 り面が発生するのも重力式擁壁と比較して遅く、その 後の変位量増大傾向も重力式擁壁と比較すると緩やか である。これは、文献(5)にて詳しく考察されているよ うに，壁面の変位と共に抵抗力として補強材周面で発 揮される張力、引き抜き抵抗が増大するためである。

補強材配置と変位量の増大傾向に着目すると、擁壁 の滑動量に関しては，HR1とHR2がほぼ同程度の耐震性 であるのに対して、HR3ではこれらよりも同加速度にお ける変位量が小さく，耐震性が高かった。一方で、転 倒角度に着目すると，HR2，HR3，HR1の順に転倒に対す る而震性が高かった。

これは，補強材周面で発揮される引き抜き抵抗の合 力が擁壁の滑動に対する抵抗力であるのに対して、擁 
壁の転倒に抵抗するのは、各層の引き抜き抵抗によっ て発揮される張力に, 補強土壁底面からの距離を乗じ た抵抗モーメントの総和であるためだと考えられる. すなわち, 前者が補強材の総延長に依存するのに対し て、後者に関しては、上層の補強材によって発揮され る張力ほど抵抗モーメントの増大に対寸る寄与が大き くなる。補強材の総延長に着目寸ると、タイプ3が最も 長く、タイプ1、2はほぼ同程度となっている。一方で、 タイプ2では最上層の補強材が最も長いために、抵抗モ 一メントの増大が顕著で，タイプ1、タイプ3よりも転 倒に対して高い耐震性を発揮したものと考えられる。

図-6にタイプ2の補強土壁に関寸る振動台実験におけ る典型的な壁面及び背面地盤の変形状況》を示す。図に 示すように、20 cmの補強材が配置されている領域(背 面補強領域)が一体的にせん断変形していることと、補 強領域の端部から発生した滑り面が、長さ $80 \mathrm{~cm}$ 補強 材の外側をかすめるようにして地表面に到達している ことが分かる。タイプ1, タイプ3の補強土壁でも補強 領域がせん断変形している事及び補強領域の端部から 滑り面が発生する事は共通の挙動であった。

図-7にHR250実験における滑動量の時刻歴を示す。 図中に示寸ように、比較的加速度レベルが低い領域で は、滑動量が非線形的な増大傾向を示しているのに対 して、滑り面の形成過程からは徐々に線形的な増大傾 向を示すとともに、変位量もそれ以前と比較すると、 若干急激に増大していることが分かる。転倒角度の増 大傾向についても同様で，これらも各タイプの補強土 壁で共通の挙動であった.

\section{（2）振動台実験より得られる知見のまとめ}

実施した振動台実験における補強土壁の地震時挙動 に関しては、下記の様にまとめられる。

(1) 補強材の配置及び総延長が変形性能に強い影響 を与える事

(2) 補強領域のせん断変形に伴い、擁壁の変位量が 増大した事

(3) 滑り面形成前は非線形的な変位量増大傾向を示 したが、滑り面形成後は変位の増大傾向が強ま ると共に、その増大傾向は線形的となった。

以下では、これらの挙動を反映して構築した変位量 の評価法について説明する。

\section{4. 計算法の構築}

\section{(1) 計算法の概要}

以下では，計算法の概要について述べる，提案手法 は，擁壁の滑動，転倒変位を対象としており，表-2に 示すように，すべり面発生前の変位量計算(Step 1), すべり面発生の判定(Step 2), すべり面発生後の変位 量計算(Step 3)の3段階で構成されている. 前述したよ うに，すべり面発生前の補強土壁は補強領域のせん断 変形と共に変位が増大していくことがわかっている. これに加えて, 補強領域直下の支持地盤がせん断変形
表-2 提案手法の概要
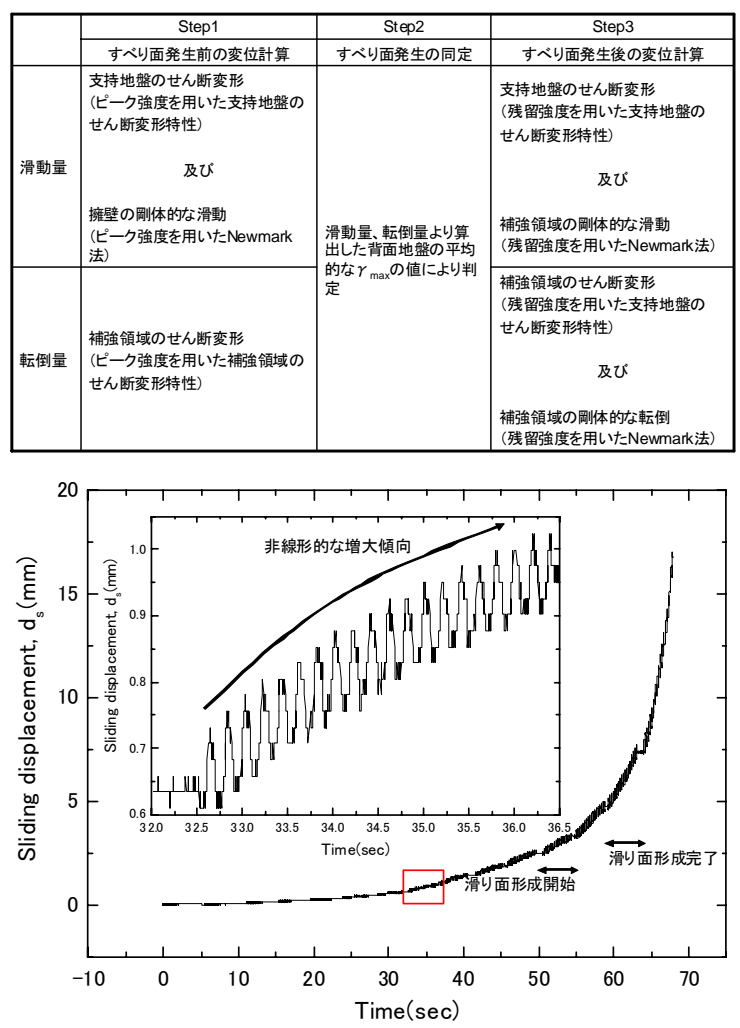

図-7＼cjkstart滑動量の時刻歴(HR2_50 実験)

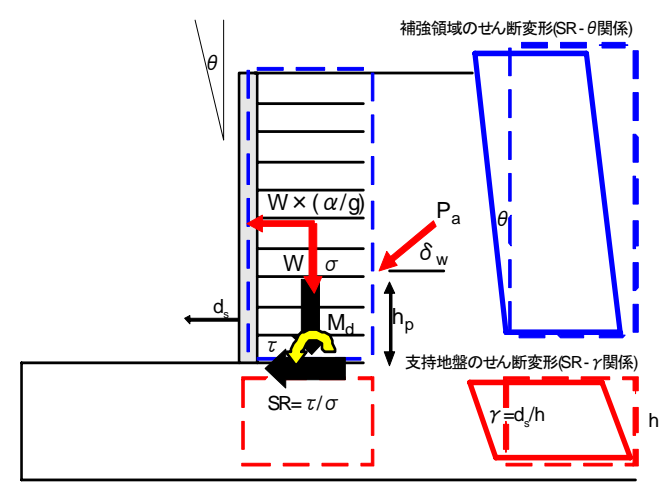

図-8 支持・背面地盤のせん断変形の模式図

する影響も無視できないことがこれまでの検討)でわか っている.

以上を踏まえて，図-8に模式的に示寸ように，Step 1でのすべり面発生前の滑動量計算においては，補強領 域直下の支持地盤におけるせん断変形を，転倒量計算 においては補強領域のせん断変形をそれぞれ考慮した。 各せん断変形特性のモデル化については後述する。な お，Step 1での変位計算では，既往の平面ひずみ試験9 の結果得られた地盤のピーク強度を用いた。

Step 2ではStep 1で求めた擁壁の滑動量, 転倒角度を 用いて，背面無補強領域の最大せん断ひずみを算出し， この值がある間值を超えていた場合には背面地盤にす べり面が発生すると想定した. すべり面が発生した場 合には計算はStep 3へと移行し，そうでない場合には 引き続きStep 1で変位を計算する.

Step 3ではすべり面発生後の変位量急増傾向を再現 
するために，補強領域の剛体的な滑動，転倒量計算及 び地盤のせん断変形特性において，ひずみ軟化の影響 を考慮した。補強領域の剛体的な滑動, 転倒変位は Newmark法によって評価し，ひずみ軟化の影響は，残留 強度を地盤の強度として使用する事により考慮した。

剛体の釣り合いを想定したNewmark法では再現できな い低加速度レベルからの非線形的な変位量増分を再現 できる事(Step 1), 背面地盤での寸べり面の発生 (Step 2) と, それに伴う変位量の急増傾向を再現できる点 (Step 3) が提案手法の特徵であり, 模型実験での地震 時挙動に対応した変形特性のモデル化となっている.

以下では, 各Stepでの変位計算法の詳細について述心゙ る.まず，Step 1，3で考慮する地盤のせん断変形特性 に関して，図-8に模式的に示したように，支持地盤及 び背面補強領域を均一な要素と想定して, 各領域に作 用するせん断応力比と，平均的なせん断ひずみの関係 を実験結果を基にしてモデル化した，以下では，これ らのせん断変形特性のモデル化ついて詳しく説明する.

\section{(2) 支持地盤のせん断変形特性}

図-8に模式的に示したように，支持地盤のせん断変 形特性は, 補強領域底部に作用寸るせん断応力比 $\mathrm{SR}(=\tau / \sigma)$ と, 平均的なせん断ひずみ $\gamma$ の関係 (以下， $S R-$ 関係)によりモデル化した。

本研究では, 補強領域底部に作用寸るせん断応力比 SRをLumped mass model(例えば, Zeghal and Elgmal ${ }^{10}$ ) を 用いて評価した。模型実験で計測した加速度時刻歴を 用いると，模型地盤中の任意深さに作用寸るせん断応 力 $\tau_{i}$ は，式(1)によって評価できる(図-9参照).

$$
\begin{aligned}
& \tau_{i}=\sum_{i=1}^{n} m_{i} a_{i}=\sum_{i=1}^{n} \rho \cdot \Delta h_{i} \cdot a_{i} \\
& \text { ここで, 式中の記号の定義は図-9を参照 }
\end{aligned}
$$

(1)式を用いて評価した $\tau_{\mathrm{i}}$ を上載圧 $\sigma_{\mathrm{v}}$ で正規化するこ とによって，補強領域底部に作用寸るせん断応力比SR を算出した. せん断ひずみ $\gamma$ に関しては，壁面の滑動量 $\mathrm{d}_{\mathrm{s}}$ を支持層の厚さhで除して算出した. 図-10にこれらの 方法で求めた $S R$ - $の$ 関係を支持地盤のせん断変形特 性として示寸，せん断変形特性のモデル化に当たって は，図-10に示した応力ひずみ曲線の包絡線を図中に併 せて示した多項式(2)によって近似した.

$$
\gamma=0.1632 \cdot S R^{3}+0.0348 \cdot S R^{2}-0.0212 \cdot S R
$$

ここで， $\gamma$ は支持地盤のせん断ひずみ， $S R$ は補強領 域底部に作用寸る平均的なせん断応力比で， $S R<$ 0.270 時, $\gamma=0$ とする.

提案手法では, 入力加速度の時刻歴より SRを評価し (図-8参照)，式(2)に代入して支持地盤のせん断変形に よる擁壁の滑動量を評価する。本研究の模型実験で用 いたような密な地盤材料の場合，比較的ひずみレベル

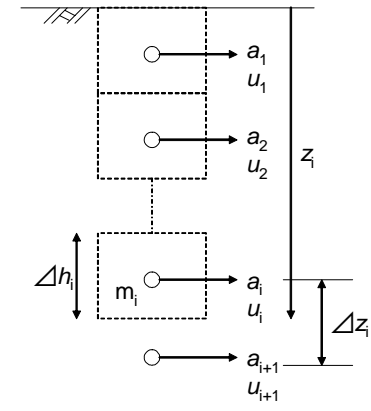

図-9 Lumped mass model で想定する地盤の模式図

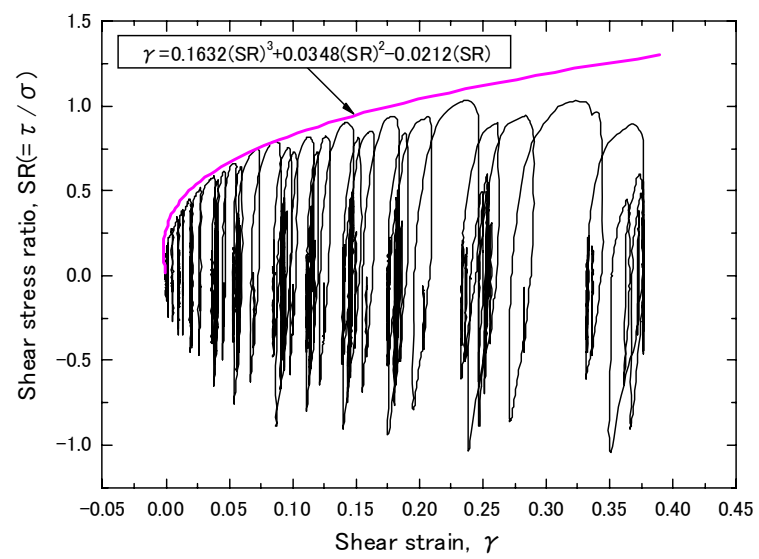

図-10 支持地盤の平均的なせん断変形特性

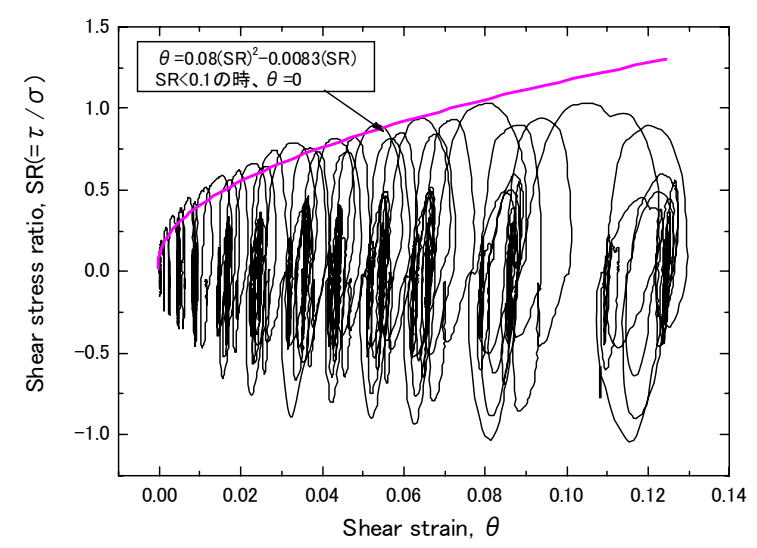

図-11 補强領域の平均的なせん断変形特性

が小さい領域では，残留変位に及ぼす繰り返し載荷の 影響は小さいので, 既往最大の $S R$ を式(2)に代入して, 支持地盤のせん断変形量を算出した. 繰り返し載荷に よるひずみ増分の影響が顕著な地盤材料の場合には, それを考慮したせん断変形特性モデルとする必要があ る（例えば累積損傷度理論による文献(6)）。

\section{（3）補強領域のせん断変形特性}

図-8に示したように，背面補強領域のせん断変形に よって, 擁壁の転倒が生じると想定した，補強領域の せん断変形特性のモデル化に当たっては, 支持地盤の 場合と同様に, 背面補強領域を均一な要素と想定した. 要素に作用寸るせん断応力比 $S R$ も支持地盤の場合と同 様に，補強領域底部に作用寸るせん断応力比をLumped 
mass model によって評価した. 補強領域の平均的なせ ん断ひずみ $\theta$ は，擁壁の転倒角度に等しいと想定して 補強領域の平均的なせん断変形特性であるSR- $\theta$ の関係 を得た。

図-11に補強領域の平均的なSR- $\theta$ の関係を示す。支 持地盤の場合と同様に，SR- $\theta$ 関係の包絡線を多項式で 近似し，式(3)により変形特性をモデル化した.

$$
\gamma=0.08 \cdot S R^{2}-0.0083 \cdot S R
$$

ここで， $\theta$ は補強領域のせん断ひずみ，SR は補強領 域底部に作用する平均的なせん断応力比で， $S R<$ $0.11 の$ 時, $\theta=0$ とする.

\section{（4）すべり面発生の判定 (Step2)}

すべり面発生の判定は，Step 1で算出した擁壁の変 位量から背面無補強領域の最大せん断ひずみ $\gamma_{\text {max }}$ 算出 して判定した. 図-12に本提案手法での $\gamma_{\text {max }}$ の算出方法を 模式的に示した。図に示す様に，滑動量を影響領域の 長さ $L(=H / \tan \xi)$ で除して水平ひずみ $\varepsilon_{\mathrm{h}}$ を算出し，鉛 直ひずみ $\varepsilon_{\mathrm{v}}$ は便宜的に等体積条件を想定して $\varepsilon_{\mathrm{v}}=-\varepsilon_{\mathrm{h}}$ とした。 また，無補強領域のせん断ひずみ $\gamma_{\mathrm{v}}$ は補強領 域のせん断ひずみ $\theta$ と等しいとして,$\gamma_{\mathrm{wh}}=\theta$ とした。

筆者らが実施した模型振動台実験についての検討 ${ }^{11)}$ では，背面地盤にすべり面が発生し始めたのは， $\gamma_{\max }$ が 約 5 \%となった段階で，約10 \%となった段階で地表面に 到達し，その形成が完了した。このため，本研究では すべり面発生に至る $\gamma_{\max }$ の閾值を5 \%に設定し， $\gamma_{\max }$ が5\% を超えると背面地盤にすべり面が発生するとして，計 算もStep 3へと移行させた. 従来型擁壁の場合には, $5 \%$ ですべり面が発生すると，ほぼ瞬時にその形成が完 了していたのに対して，補強土壁ではすべり面の形成 が完了するのに更なる累積変形を要した.

また，最大せん断ひずみ5％,10％はそれぞれ既往の 平面ひずみ圧縮試験(文献(9))におけるピーク時ひずみ と残留強度に収束した時点でのひずみにほぼ対応して いた。このように，擁壁背面地盤におけるすべり面の 発生は要素試験でのピーク強度発揮後のひずみの局所 化とせん断層の形成に対応しており，実際の擁壁の変 形挙動の予測に当たって，すべり面発生に至る最大せ ん断ひずみの值を設定する際には、要素試験の結果が 利用できると考えられる.

\section{(5) 閾値加速度及びモーメントの設定}

前述した地盤変形に伴う擁壁の変位量増分に加えて, 提案手法では，補強領域が一体となって剛体的に変位 する事による滑動，転倒量増分も考慮した。これらの 変位増分は, Newmark法によって評価しており, 以下で はNewmark法での変位量計算に必要な閾值の算出方法に ついて述べる.

Newmark法での変位量計算に用いる閾值加速度 $\alpha_{\text {thres }}$ 及 び閾值モーメント $M_{\text {thres }}$ は補強領域を剛体と想定した上 で，補強領域への作用力と抵抗力（あるいは作用モー

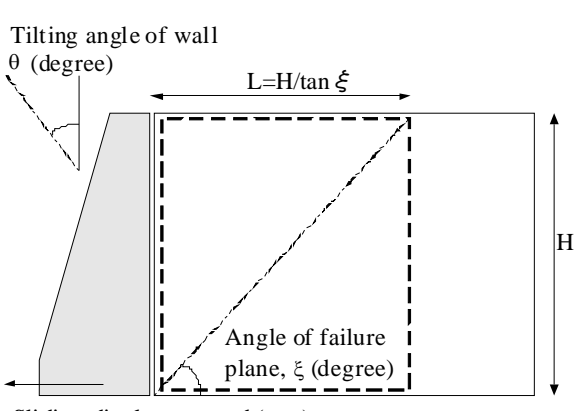

Sliding displacement, $\mathrm{d}_{\mathrm{s}}(\mathrm{mm})$

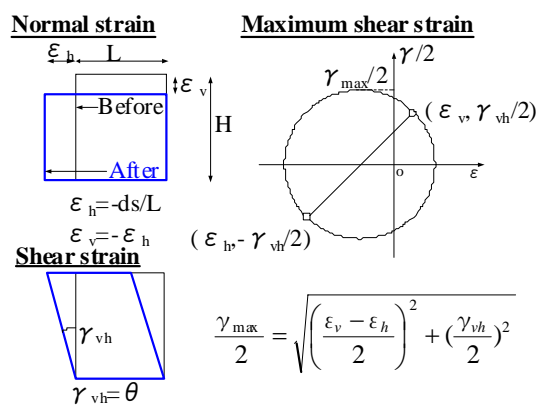

図-12 背面無補強領域における $\gamma_{\max }$ の算出
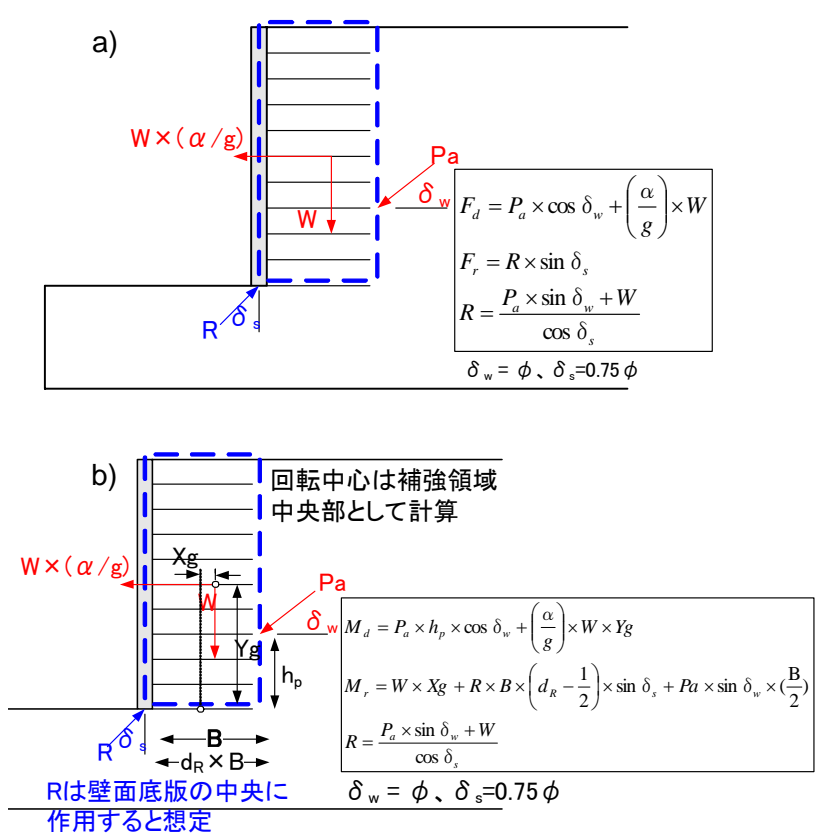

図-13 閾值の算出方法のまとめ

メントと抵抗モーメント）が等しくなる加速度，モー メントをそれぞれ $\alpha_{\text {thres }}, M_{\text {thres }}$ に設定した.

図-13(a), (b)に $\alpha_{\text {thres, }}, M_{\text {thres }}$ 算出時の力の釣り合いの模 式図を示す。図-13(a)に示すように，擁壁を滑動させ る作用力として, 補強領域背面に作用する地震時土圧 の水平成分と, 補強領域に作用する慣性力を想定し, 抵抗力として補強領域底部でのせん断抵抗を考慮した. 地震時土圧は，すべり面発生前はピーク強度を用い

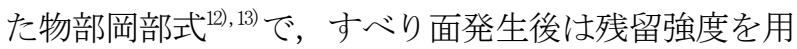
いて修正物部岡部式 ${ }^{14)}$ で算出した。 ピーク強度 $\phi_{\text {peak }}$, 残留強度 $\phi_{\text {res }}$ は既往の平面ひずみ試験結果から，それ ぞれ51度，43度に設定した．背面補強領域と無補強領 域との間の摩擦角 $\delta_{\mathrm{w}}$ (土圧合力の水平方向に対する傾 
表-3 解析条件のまとめ

\begin{tabular}{|c|c|c|c|c|c|}
\hline 解析ヶース & $\begin{array}{c}\xi \text { (degree) } \\
\text { (実測值) }\end{array}$ & $\begin{array}{c}\alpha_{\text {thres }}(\mathrm{p}) \\
(\mathrm{gal})\end{array}$ & $\begin{array}{c}\alpha_{\text {thres }}(\mathrm{r}) \\
(\mathrm{gal})\end{array}$ & $\begin{array}{c}\mathrm{M}_{\text {thres }}(\mathrm{p}) \\
(\mathrm{Nm} / \mathrm{m})\end{array}$ & $\begin{array}{c}\mathrm{M}_{\text {thres }}(\mathrm{r}) \\
(\mathrm{Nm} / \mathrm{m})\end{array}$ \\
\hline HR1 & $20.6(51)$ & 720 & 381 & $*$ & 514 \\
\hline HR2 & $20.6(40)$ & 720 & 381 & $*$ & 514 \\
\hline HR3 & $19.2(30)$ & 737 & 444 & $*$ & $*$ \\
\hline
\end{tabular}

*閜俌が著しく大きくなり、今回の計算条件では変位が発生しない

斜角度）、支持地盤と補強領域底部との間の摩擦角 $\delta \mathrm{s}$ はそれぞれ $\delta_{\mathrm{w}}=\phi ， \delta_{\mathrm{s}}=0.75 \phi$ に設定した(図-8参照).

一方で，モーメントの算出においては図-13(b)に示 した様に，回転中心を補強領域底部の中央に設定した. 補強領域の転倒に寄与寸るモーメントは，地震時土圧 の水平成分及び補強領域に作用する慣性力によって生 じると想定した．これに対して，地震時土圧の鉛直成 分と，支持地盤からの反力がこれに抵抗するものと想 定した．なお，本解析では土圧合力は擁壁高さの $1 / 3 の$ 位置に作用し，支持地盤からの反力は壁面の中央部に 作用するものと想定した．これは，本提案手法で想定 しているようなモードで補強領域が転倒する際には, 補強領域前面底部, 特に周辺の地盤と比較して岡性の 高い壁面部に支持地盤からの反力が集中寸ると考えら れるためである.

以上のような条件で，加速度を 1 galから徐々に増大 させ，滑動力=滑動抵抗力あるいは転倒モーメント=抵 抗モーメントとなった時の加速度あるいモーメントを $\alpha_{\text {thres }}, M_{\text {thres }}$ に設定した. 具体的な $\alpha_{\text {thres }}, M_{\text {thes }}$ の計算結 果については次の計算結果の項で説明する.

\section{5. 計算結果}

\section{(1) 計算手順}

以下では実際の計算手順について説明する。

(1). 図-8に示した力の釣合いの模式図のもとで，入力 加速度の時刻歴から, 補強領域底部に作用寸る $S R$, M を算出する。この時，地盤の強度としてはピー ク強度を用いる。

(2). 算出したSRの時刻歴を式(2)，(3)に代入して，地 盤のせん断変形による擁壁変位量の増分を求める.

(3). $\alpha_{\text {thres }}, M_{\text {thres }}$ を用いてNewmark法により補強領域の剛 体的な変位量を算出する (本研究で解析対象とし た実験模型の閾值は，表-3を参照).

(4). (2), (3)で求めた変位量を合計して, 擁壁の滑動量, 転倒角度を算出する (1)～(4)，Step 1)。

(5). (4)で求めた変位量から, 背面無補強領域の最大せ ん断ひずみを算出する．算出した最大せん断ひず みが5 \%を超えていた場合には滑り面が発生する ものとして, Step 3に移行する．5\%未満の場合に は，引き続きStep 1で変位計算を行う (Step 2).

(6). すべり面発生後の変位量急増傾向を再現するため に，残留強度で評価した $S R ， M_{\mathrm{d}}$, 闇值加速度，閾 值モーメントを用いて変位量計算を行う (Step 3). 以下では，以上の提案手法を振動台実験に適用した 解析結果について述べる.
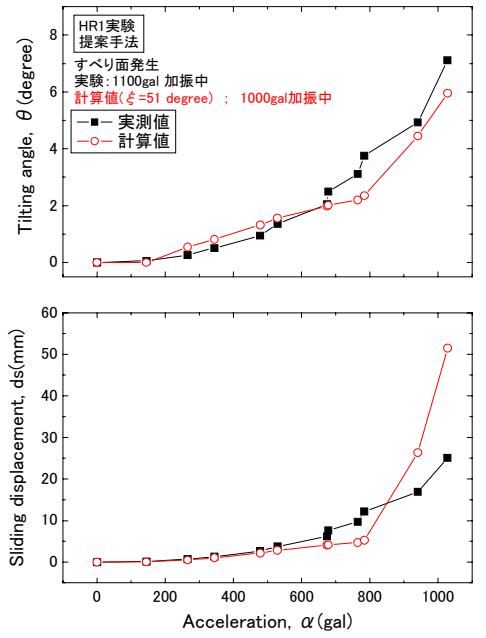

図-14 計算值と実測值の比較 (HR1 実験)
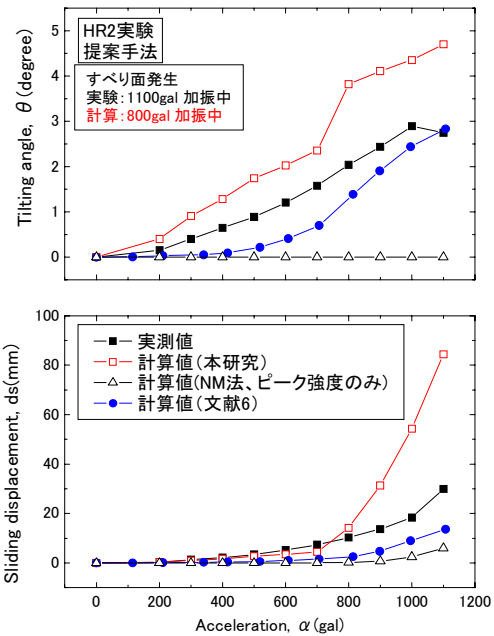

図-15＼cjkstart計算值と実測值の比較(HR2 実験)

\section{（2）振動台実験の計算結果}

本研究では, 振動台実験の結果に対する提案手法の 適用を試みた。対象とした実験は，補強材配置の異な るHR1,HR2, HR3の3実験である. 図-14〜16に各実験での 計算値と実測值との比較を示す．図-15には既往の計算 手法（文献6）による計算結果に加えて, Newmark法の 計算結果として，表-3中のピーク強度時の閾值のみで の計算結果も示した。なお，各図中では，計算上のす べり面発生タイミングも実際のものと比較している.

図-14に示すように，HR1実験では計算值と実測值が 比較的良好に整合しており，すべり面の発生タイミン グも害際の挙動を良く予測できていた.

それに対して，図-15に示したHR2実験では，計算值 は実測值を過大評価していた。一方で，既往の提案手 法による計算結果は変位量を過少評価する傾向にあっ た.ただし，本研究、既往の提案手法共に無補強領域 まで延長された中層，最上層の補強材によって発揮さ れる引抜抵抗の影響を考慮していないため、この影響 を考慮すると，両者ともに計算值が減少してくると考 えられる．筆者ら 

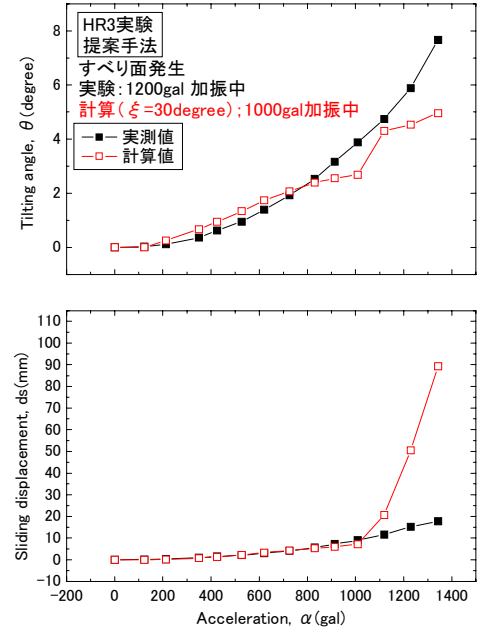

図-16 計算值と実測値の比較 (HR3 実験)

施している．この結果をもとにして引抜抵抗の効果を 導入して今後提案手法を改善していく予定である.

また，Newmark法による計算值は実測值を顕著に過少 評価しており，剛体釣合いのみを考慮したNewmark法で は，補強領域及び支持地盤の変形の影響を考慮できな いため，特に比較的低い加速度レベルにおける補強土 壁の地震時挙動を再現する事が困難だった.

図-16に示した HR3 実験についての計算結果は，1000 gal程度までの加速度レベルにおいては，計算值と実測 值は比較的良好に整合しているものの，それ以降では 計算值，特に滑動量は実測值を著しく過大評価してい た. 提案手法では, 補強領域直下の支持地盤せん断変 形々, 補強領域の岡体的な滑動変位を別々に算出し, 補強土壁の滑動をモデル化している。しかし，実際に は補強領域は剛体ではなく, 図一6に示したように補強 領域がせん断変形寸ることにより，剛体的な滑動に寄 与寸るエネルギーが吸収される事になるため，特に大 加振レベルにおいてこの事を考慮していない提案手法 で，擁壁の滑動量を過大評価したものと考えられる.

一方，転倒に関しては，元々補強領域全体の転倒に対 寸る安定性が高く $\left(M_{\text {thres }}\right.$ が大きく $)$, 補強土壁の転倒変位 に占める補強領域の岡体的な変位の影響が小さかった ために，実測值との乘離が生じなかったと考えられる.

\section{（2）被災事例の計算結果}

1995年の兵庫県南部地震における被災事例について, 提案手法によって残留変位量を評価し，提案手法の実 物大擁壁への適用性についても検証した. 被災擁壁の 断面図及び解析条件を図-17に示寸．解析対象とする補 強土壁は，タナタ地区に建設されていた鉄道盛土を支 えていた剛な一体壁面を有寸る補強土壁である.

この地域はNS方向の最大加速度として818 galが計測 された神戸海洋気象台の近傍で，解析対象とした補強 土壁は当該地震で，最も激震にさらされた地域に建設 されていた．地震後の調査により，壁面底部，天端の 水平変位がそれぞれ約 $0.10 \mathrm{~m}, 0.24 \mathrm{~m}$ で，壁面に約 1.8 度程度の傾斜が生じたことがわかっている。しかし，

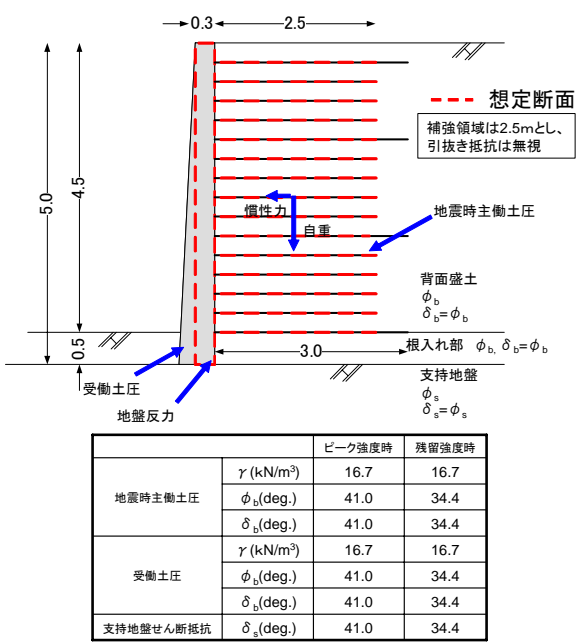

図-17 解析対象とした被災擁壁と解析条件のまとめ

表-4 閾值のまとめ

\begin{tabular}{|c|c|c|c|c|c|}
\hline 解析ケ一ス & $\xi(\mathrm{deg})$ & $\begin{array}{c}\alpha_{\text {trese( }}(\mathrm{p}) \\
\text { (gal) }\end{array}$ & $\begin{array}{c}\alpha_{\text {thesea }}(r) \\
\text { (gal) }\end{array}$ & $\begin{array}{l}M_{\text {nins }}(p) \\
(\mathrm{kNN} / \mathrm{m})\end{array}$ & $\begin{array}{l}\begin{array}{l}M_{\text {tives }}(r) \\
(\mathrm{kNN} / \mathrm{m})\end{array}\end{array}$ \\
\hline 夕ナタ禣強土擁壁 & 22.4 & 589 & 487 & *t* & **t \\
\hline
\end{tabular}
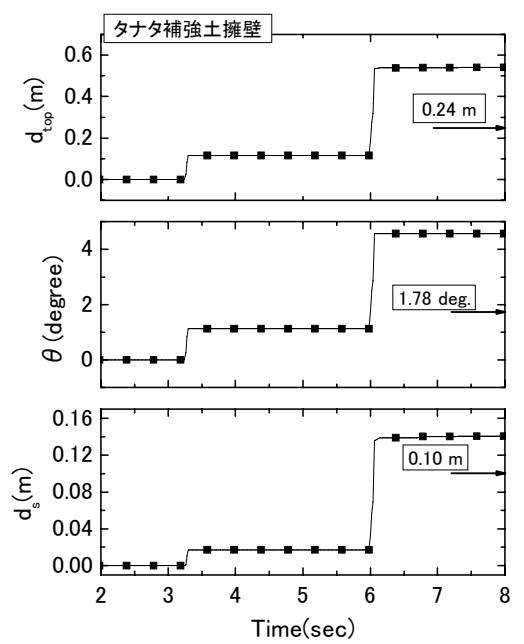

\section{図-18＼cjkstart解析結果と震後の変位測定結果の比較}

周辺に建設されていた従来型擁壁が甚大な被害を受け た事と比較すると，その被害程度は極めて軽微で，簡 易な補修後に供用を再開した (文献(1))。提案手法によ る解析を実施する際には，解析上の利便性のために， 図-17に示寸ように擁壁断面を若干単純化し，解析に用 いる土質定数他の物性值は文献(1) を参照して決定した。

図-17に示すように，壁面根入れ部の前面地盤から作 用する受働土圧も抵抗力として考慮した. 図-17に示し た力の釣り合いの模式図から, 神戸海洋気象台での観 測波形(NS成分) 用いて補強領域底部に作用寸るせん 断応力比 $S R$, 作用モーメントM

Newmark法での変位量計算に必要な閾值加速度も前項 （5）でまとめた通りの方法で算出した．表-4に解析で用 いた $\alpha_{\text {thress }}, M_{\text {thres }}$ の值をまとめた． $M_{\text {thres }}$ に関しては, 818 gal以下では作用モーメントが抵抗モーメントを上回る ことが無かった．本解析においては，支持地盤及び背 面補強領域のせん断変形特性として, 振動台実験の結 果より評価した式(2)，式(3)を用いた。 
提案手法による計算值と，地震後の調査で計測した 壁面の変位との比較を図-18に示寸．壁面天端の変位 $d_{\mathrm{top}}$ は, 提案手法で評価した $d_{s}, \theta$, 壁面高さより算出した. 図に示すように，計算值は若干変位量を過大評価して いるものの実測值と比較的良好に整合しており，提案 手法が実際の擁壁に対しても，適用可能ではあること が確認できた。今後は被災事例の他，無被災の事例な どに対して適用し，被害・無被害を適切に再現できる のか，また，被害の程度についても実務上での適用に 耐えうる精度で評価できるのかについて，さらに検証 していく予定である.

\section{6. まとめ}

地盤変形とひずみ軟化の影響を考慮した補強土壁の 変位量計算手法を構築し, 既往の模型振動台実験, 及 び被害事例に対して提案手法を適用する事で，その妥 当性を検証した．計算の結果，幾つかの課題は残され ているものの提案手法による計算值は振動台実駼結果, 実被害事例共に，比較的良好に再現することが出来た.

\section{謝辞}

本研究で実施した振動台実験の実施に当たっては, (株)複合技術研究所のご協力を頂いた。 また，提案手 法の基本的なコンセプトの構築については, 特許庁(前 東京大学大学院) の加藤範久氏の貢献による所が多大で ある。記して謝意を表する。

\section{参考文献}

1) Tatsuoka, F., Koseki, J., Tateyama, M., Munuf, Y. and Horii, K., Seismic stability against high seismic load of Geosynthetic-Reinforced soil retaining structures, Keynote lecture, Proc. of the 6th Intemational Conference on Geosynthetics, Vol.1,pp.103-142., 1998

2）鉄道総合技術研究所，鉄道構造物等設計標準 - 同解説 土構造物，丸善株式会社，2007

3）堀井克己，舘山勝，古関潤一，龍岡文夫，剛壁面補強土
壁の大規模地震時の安定・変形解析, ジオシンセティッ クス論文集，第13巻，pp. 1749-1750, 1998

4) Newmark N.M., Effects of earthquake on dams and embankments, Geotechnique, Vol15, No.2, pp.139-160, 1965

5) Watanabe, K., Munuf, Y., Koseki, J., Tateyama, M. and Kojima, K., Behaviors of Several Types of Model Retaining Walls Subjected to Inegular Excitation, Soils and Foundations, Vol.43, No.5, pp. 13-27., 2003

6）古関潤一，加藤範久，渡辺健治，舘山勝，補強土擁壁と 重力式擁壁の地震時変位量の簡易計算手法, ジオシンセテ イックス論文集，第18巻，pp. 367-374., 2003

7）中島進, Kimhor Hong, Sarju Mulmi, 古関潤一, 渡辺健治, 舘山勝，異なる補強材を用いたジオグリッド補強土擁壁 の模型振動台実験，第22回ジオシンセティックスシンポジ ウム, pp.191-198., 2007

8）中島進、古関潤一、佐藤剛司，振動台実験における擁壁 模型支持地盤のせん断変形特性，第43回地盤工学研究発表 会, 2008

9) Munuf, Y., Study on seismic performance of soil retaining walls by tilting test and shaking table tests, 東京大学 博士論文, 1998

10) Zeghal, M. and Elgamal, A. W., Analysis of site liquefaction using earthquake records, Joumal of Geotechnical Engineering, Vol.120, No.6, ASCE, pp.996-1017., 1994

11) Nakajima,S., Koseki, J., Watanabe, K. and Tateyama, M., Evaluation of allowable displacement of retaining walls by shaking table model tests, Proc. of the 6th Intemational Conference on physical modeling in geotechnics, Hong Kong, Vol.2,pp.1101-1106., 2006

12) Okabe, S. , General theory of earth pressure, Proc. of Japan Society of Civil Engineers, Vol.12, No.1, pp.123-134., 1926

13) Mononobe, $N$. and Matsuo, $H$, On determination of earth pressure during earthquake, Proc. of World Engineering Congress, Vol.9, pp.177-185., 1929

14）Koseki, J., Tatsuoka, F., Munuf, Y., Tateyama, M. and Kojima, K., A modified procedure to evaluate active earth pressure at high seismic loads, Soils and Foundations, Special Issue on Geotechnical Aspect of the January 17 1995 Hyogoken-Nanbu earthquake, No.2, pp.209-216, 1998

Development of a procedures to evaluate earthquake-induced residual displacements of geosynthetics reinforced soil retaining wall and its application to case history

\section{Susumu Nakajima, Junichi Koseki, Kenji Watanabe and Masaru Tateyama}

A displacement evaluation method of geosynthetics reinforced soil retaining walls was developed based on results from series of shaking table model tests. Proposed method can simulate nonlinear increments of the wall displacement, which were observed from low acceleration level in the shaking table model tests, by considering deformations of subsoil layer and reinforced backfill. Accumulations of displacement increments after failure plane formation in backfill layer was also taken into account by considering effects of strain softening behaviors of backfill soils. Computed displacements using the proposed method corresponded well with the measured ones in the shaking table model tests while the effects of the pullout resistance should be considered for further improvements. The applicability of the proposed method to prototype scale retaining wall was also examined based on an analysis on the case history in the 1995 Hyogo ken Nanbu-earthquake, Japan. 